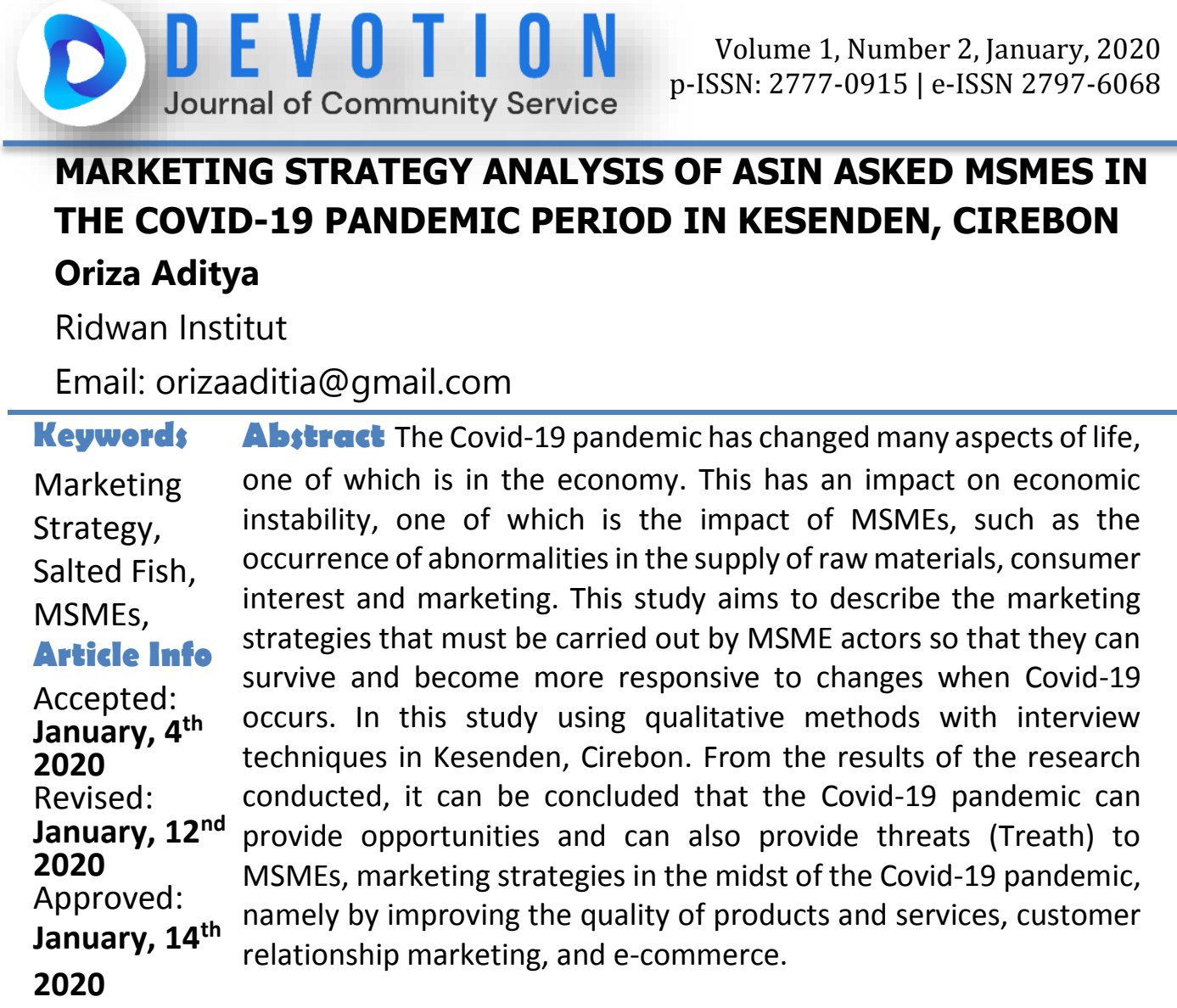

\title{
Introduction
}

The Indonesian MSME industry is currently facing such a difficult situation amid the changing business environment which is increasingly complex (Wibowo, Arifin, \& Sunarti, 2015) Since the Covid-19 pandemic that hit Indonesia in March 2020, many life arrangements have changed. Starting from the education, tourism and economy sectors. This pandemic is changing people's behavior so they always keep their distance (social distancing) and don't crowd. The public is increasingly afraid of the spread of this virus and to break the chain of spreading Covid-19, the government has issued a Large-Scale Social Restriction (PSBB) regulation in areas with high cases. National economic development is not only the responsibility of the government, but also a shared responsibility(McGee, Brenneman, \& Spector, 1977). The development of the internet also has influenced economic development (Kurniawati \& Arifin, 2015).

With the existence of this PSBB, many people experienced layoffs (PHK), which made them have no financial income and chose to save expenses because they did not know how long this pandemic would last. This condition weakens the nation's economy due to decreasing public purchasing power, this puts pressure on 


\section{Oriza Aditya}

producers and sellers. Many companies or entrepreneurs do not survive in this situation and some choose to stay even though there are few or no buyers.

Micro, Small and Medium Enterprises (MSMEs) are an important part of the economy of a country or a region, including in Indonesia. Sector development (Wibowo et al., 2015). Micro, Small and Medium Enterprises (MSMEs) are an important part of the economy of a country or a region, including in Indonesia. Sector development (Jamil, Kurnia, \& Jalaludin, 2020).

Based on a study by the Ministry of Finance (Kemenkeu), Covid-19 poses negative threats to the economy, such as a decrease in people's purchasing power, a decline in company performance, threats to the banking and financial sectors, and the existence of MSMEs. In the aspect of MSMEs, the existence of this pandemic has caused a decline in performance from the demand side (consumption and purchasing power of the community) which ultimately has an impact on the supply side, namely termination of employment and the threat of non-performing credit payments (Pakpahan, 2020).

According to the Ministry of Cooperatives and Small and Medium Enterprises, there are around 37,000 MSMEs who report that they are very seriously affected by this pandemic, marked by around 56 percent reporting a decrease in sales, 22 percent reporting problems in the aspect of financing, 15 percent reporting problems with distribution of goods, and 4 percent reporting difficulty getting raw materials (Riska, 2020).

According to data from the Ministry of Cooperatives, Small and Medium Enterprises (KUKM) in 2018, the number of MSME players was 64.2 million or 99.99\% of the number of business actors in Indonesia. The absorption capacity of the UMKM workers is as much as 117 million workers or $97 \%$ of the absorption capacity of the workforce of the business world. Meanwhile, the contribution of MSMEs to the national economy (GDP) was $61.1 \%$, and the remaining $38.9 \%$ was contributed by large business actors, which amounted to only 5,550 or $0.01 \%$ of the total business actors.

The challenge for MSMEs during this pandemic condition is a decrease in demand, as experienced by salted fish MSMEs in RW 11 Kesenden Village, Kejaksan District, Cirebon City. Changes that occur are quite impactful, but 
adjustments must be made to these conditions so that MSMEs can continue to survive despite a decrease in income, limited marketing, and reduced availability of raw materials.

The majority of people who live in RW 11 Kelurahan Kesenden work as fishermen and makers of salted fish. The manufacture of salted fish comes from fresh fish which is then processed into salted fish. The selling price of salted fish varies depending on the type and the scarcity of raw materials.

Before entering the market, producers must know information about market conditions, target markets such as high consumer demand or not because this affects their production and marketing strategies. In the production process, the quality of the products produced must be good and the service to consumers must also be satisfying because this will affect customer trust so that it will increase customer loyalty.

During this pandemic, there were many abnormalities such as supply of raw materials, consumer interest and marketing. Based on this, the author wants to examine what MSMEs can do to be able to maintain their business during the Covid-19 pandemic. This study aims to describe the marketing strategies that must be carried out by MSME actors so that they can survive and become more responsive to changes when Covid-19 occurs.

\section{Method Research}

This study uses a qualitative method that intends to explain a phenomenon in depth by collecting data as deep as possible, which shows the importance of the depth and detail of the data being studied (Oky, 2020).

The data collection technique used in this study was interviews. Interviews can be used as a data collection technique if the researcher finds a problem that must be studied, and the researcher wishes to know more deeply about the things related to the informant. Interviewing is a data collection technique to obtain information extracted from direct data sources through conversations or questions and answers. Interviews in qualitative research are in-depth because they want to explore information holistically and clearly from informants (Ayudha, 2015).

In this study, data sources are divided into two, namely, primary data and secondary data. Primary data in the form of data obtained from empirical research results through in-depth analysis of parties directly related to the management of 


\section{Oriza Aditya}

salted fish MSMEs in economic empowerment. Meanwhile, secondary data in this study are reference sources such as scientific books, knowledge books, journals, the internet and other media that can be used as references. The analysis used is descriptive analysis and SWOT analysis. The research was conducted in Kelurahan Kesenden with the object of research in the form of Salted Fish UMKM.

\section{Result and Discussion}

\section{Profile of Salted Fish Business in Kelurahan Kesenden}

Production is the activity of producing goods or services or activities that add value to the use or benefits of an item. In the book Production Operations Management (2020) Andy Wijaya and friends, production is the process of producing something in the form of goods and services in a period of time and has added value for the company (Welianto, 2020).

One of the factors that determine success is the raw material. The raw materials in the process of making salted fish are fresh and salt fish, there is also the manufacture of unsalted fish using ice cubes. The drying process takes 4 days if it's raining and 2 days when it's hot.

The types of fish that are processed into salted fish are bilis, tigawaja, snapper, grouper and mixed fish. These fresh fish are obtained from areas around the production site and can reach out of town such as in Indramayu, Gebang, and Semarang.

For the price of salted fish the most expensive is bilis, which reaches Rp. 80,000 Rp. 100,000 / kg, for tigawaja fish Rp. 70,000 / kg and mixed fish Rp. 60,000 / kg. The sales system is by ordering via telephone and is marketed in Cirebon to Bandung.

\section{Analysis SWOT}

a. Strenght

The strengths in the MSME business of salted fish in Kelurahan Kesenden, District Kejaksan are: 
1) Raw material

Raw materials are obtained from fresh fish and processed in a good process. The more raw materials, the faster the production process.

2) Packaging Good packaging will be able to maintain product quality.

b. Weakness

The weaknesses in the salted fish UMKM business in Kelurahan Kesenden, Kejaksan District are:

Raw materials can also be a drawback if they are difficult to find, such as blackfish.

c. Opportunity

The opportunities in the salted fish UMKM business in Kelurahan Kesenden, Kejaksan District are:

1) market demand is too high

The marketing of salted fish in Kelurahan Kesenden is not only in the Cirebon area, but has also left cities such as Bandung and Garut. Seeing this condition, it means that this salted fish product is favored and trusted by the outside community and it is possible that it will expand again to several cities.

2) Digital marketing

With the entry of industry 4.0 and due to the Covid-19 pandemic, the average sales are made online through the marketplace and promotion via social media, but these MSMEs have not made online sales.

d. Treath

The threats in the MSME business of salted fish in Kelurahan Kesenden, District Kejaksan are:

1) Higt rainfall

High rainfall is a threat to salted fish, especially if it has entered the rainy season. The drying process will take longer and marketing is also hampered.

2) Pandemic Covid-19

As a result of the Covid-19 pandemic, all activities were limited to leaving the house, causing a decrease in sales in the market. In addition, production activities are also disrupted due to the difficulty of accessing raw materials outside the city.

\section{Marketing Strategy During the Covid-19 Pandemic}

\section{a. Product and Service Quality Improvement}




\section{Oriza Aditya}

The occurrence of the Covid-19 pandemic has made consumers more careful in choosing types of food, consumers will choose a healthy diet so that the body's immune system is immune to viruses. Not only diet, but the quality of the selected product must also be of high quality. The quality of a product can also increase consumer confidence, for that MSME actors of salted fish are required to make improvements to product quality and inform these advantages with the aim of increasing consumer confidence.

Research (Haryanto, 2013) states that product quality has a significant effect on customer satisfaction. For this reason, salted fish SMEs need to pay attention to product quality to increase consumer confidence during the Covid-19 pandemic The aspect that needs to be considered regarding the product is the quality of the product. Kotler and Armstrong (2004: 283) state product quality as "the ability of a product to perform its functions. Its includes the product's overall durability, reliability, precision, ease of operation and repair, and other valued attributes".

This means that product quality is closely related to the product's ability to perform its functions, including the overall product, reliability, accuracy, ease of operation, repair and other valuable attributes. So product quality is a set of features and characteristics of goods and services that have the ability to meet needs, which is a combined understanding of reliability, density, convenience, maintenance and other attributes of a product.

The products offered by each business entity will be different and definitely have characteristics that differentiate the product from competing products even though the types of products are the same so that the product has uniqueness, features, excellence in reaching the targeted market(Shandy Widjoyo Putro dan Hatane Semuel, 2014).

In addition to improving product quality, salted fish SMEs must also improve the quality of services, such as delivery services or purchases via hotlines. With advances in technology today, it is easier to obtain a wide market. Business actors can take advantage of this method in the midst of the Covid-19 pandemic situation, which forces them to keep their distance and stay at home. Therefore, improving product quality is not only in product content but also on packaging to 
maintain durability and safety during delivery.

\section{b. Customer Relationship Marketing}

In the Covid-19 pandemic situation, it might be difficult if you want to get new customers. Therefore, one way to maintain the salted fish MSME business is to maintain existing or loyal customers. Then to create long-term relationships with customers, it must maintain a mutually beneficial relationship between service providers or products and customers so that customer loyalty is created or what is called the concept of Customer Relationship Marketing.

According to Farida's research in (Hardilawati, 2020) customer relationship marketing has a positive and significant effect in improving the marketing performance of MSMEs through improving the quality of relationships and entrepreneurial orientation. The better the quality of the relationship between MSME actors with consumers, suppliers and others, the better the ability to improve their marketing performance.

In addition, business actors who dare to take risks, already have experience in business and are flexible towards business, can increase networks and foster trust from consumers, so that consumers will survive. Different research results were obtained in research (Hardilawati, 2020) which obtained results that customer relationship marketing had a positive but insignificant effect on improving the performance of MSMEs. This is because SMEs have limitations and have not been maximal in carrying out customer relationship marketing.

\section{c. E-Commerce}

E-Commerce in general can be defined as buying and selling transactions electronically through the internet media. In addition, e-commerce can also be interpreted as a process of doing business using electronic technology that connects companies, consumers and the public in the form of electronic transactions and the exchange or sale of goods, services and information electronically (Hardilawati, 2020).

According to research (Helmalia, 2018), e-commerce has a significant effect on revenue. Meanwhile, according to (Tiandra, 2019) the use of e-commerce does not have a significant effect on the performance of MSMEs. Although e-commerce does not have a significant effect on the performance of MSMEs, the presence of e-commerce is one of the marketing alternatives used to reach more customers. 


\section{Oriza Aditya}

UMKM can do promotions anywhere and anytime for 24 hours without stopping. This transaction model allows transactions across regional boundaries much more easily and in a cost effective manner than traditional trading.

The Covid-19 pandemic situation that occurred is very beneficial for business actors who take advantage of e-commerce. Consumers are reluctant to leave because of the danger of the Covid-19 virus, so they take more advantage of ecommerce to meet their needs. This is one way for Salted Fish MSMEs to expand market share and increase sales in this situation. Examples of e-commerce taking off in the midst of a pandemic are Vegetable Box, Go-Daily, Etanee, TaniHub and Happy Fresh (Aderianti, 2018).

\section{Conclusion}

The conclusion from the analysis of the marketing strategy of salted fish Micro, Small and Medium Enterprises (MSMEs) during the Covid-19 pandemic in the Kelurahan Kesenden, District Kejaksan, Cirebon City is as follows: Production is an activity to produce goods or services or an activity that adds value to the use or benefits of an item. One of the factors that determine success is the raw material, This Covid-19 pandemic can provide opportunities and can also threaten (Treath) to salted fish MSMEs, depending on how to respond and try to adapt to the situation that occurs, Marketing strategies in the midst of the Covid-19 pandemic, namely by improving the quality of products and services, customer relationship marketing, and e-commerce.

\section{References}

Aderianti, Sindhi. (2018). 5 Aplikasi Pangan Terpopuler Di Indonesia, Sudah Coba? Ayudha, Puspita. (2015). Teknik Pengumpulan Data. Universitas Pendidikan Indonesia.

Hardilawati, Wan Laura. (2020). The Survival Strategy Of Smes During The Covid19 Pandemic. Jurnal Akuntansi \& Ekonomika, 10(1). 
Haryanto, Resty Avita. (2013). Strategi Promosi, Kualitas Produk, Kualitas Layanan Terhadap Kepuasan Pelanggan Pada Restoran Mcdonald's Manado. Jurnal Emba, 1.

Helmalia, Afrinawati. (2018). Pengaruh E-Commerce Terhadap Peningkatan Pendapatan Usaha Mikro Kecil Dan Menengah Di Kota Padang. Jurnal Ekonomi Dan Bisnis Islam, 3(2).

Jamil, Nindi Apridha, Kurnia, Asep Dede, \& Jalaludin, Jalaludin. (2020). Analisis Mekanisme Praktik Jual Beli Followers Dalam Perspektif Ekonomi Islam Di Media Sosial Instagram. Eksisbank: Ekonomi Syariah Dan Bisnis Perbankan, 4(1), 82-94. Https://Doi.Org/10.37726/Ee.V4i1.101

Kurniawati, Dewi, \& Arifin, Nugraha. (2015). Strategi Pemasaran Melalui Media Sosial Dan Minat Beli Mahasiswa. Jurnal Simbolika, I, 193-198.

Mcgee, Richard, Brenneman, Douglas E., \& Spector, Arthur A. (1977). Regulation Of Fatty Acid Biosynthesis In Ehrlich Cells By Ascites Tumor Plasma Lipoproteins. Lipids, 12(1), 66-74. Https://Doi.Org/10.1007/Bf02532975

Oky, Sugianto. (2020, April). Penelitian Kualitatif, Manfaat Dan Alasan Penggunaan. Binus University, 1.

Pakpahan, Aknolt Kristian. (2020). Covid-19 Dan Implikasi Bagi Usaha Mikro, Kecil,

Dan Menengah. Fakultas IImu Sosial Dan IImu Politik, O(0), 59-64. Https://Doi.Org/10.26593/Jihi.V0i0.3870.59-64

Riska, Rahman. (2020, April). 37,000 Smes Hit By Covid-19 Crisis As Government Prepares Aid. The Jakarta Post, P. 1.

Shandy Widjoyo Putro Dan Hatane Semuel, Ritzky Karina M. R. Brahmana. (2014). Pengaruh Kualitas Layanan Dan Kualitas Produk Terhadap Kepuasan Pelanggan Dan Loyalitas Konsumen Restoran Happy Garden Surabaya. Jurusan Manajemen Pemasaran, 2(1).

Tiandra, Nanda. (2019). The Effect Of E-Commerce On Msme's Performance Improvement (Case Study On Msme's In Sumbawa District). Jurnal Ekonomi Dan Bisnis Indonesi, 04. 


\title{
Oriza Aditya
}

Welianto, Ari. (2020, July). Produksi: Pengertian, Tujuan, Dan Faktornya. Kompas.Com.

Wibowo, Dimas Hendika, Arifin, Zainul, \& Sunarti. (2015). Analisis Strategi Pemasaran Untuk Meningkatkan Daya Saing Umkm (Studi Pada Batik Diajeng Solo). Jurnal Administrasi Bisnis (Jab), 29(1), 59-66.

\author{
$* * *$ \\ Copyright holder : \\ Oriza Aditya (2020) \\ First publication right : \\ Devotion - Journal of Community Service \\ This article is licensed under:

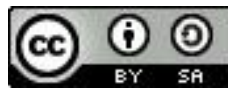

